\title{
Enunciación
}

\section{El papel del contexto en la comprensión de la ironía verbal. Análisis pragmático de una muestra}

\author{
The Role of the Context in the Understandling of Verbal Irony. \\ Pragmatic Analysis of a Sample \\ Freddy Alberto Mier Logato*
}

\section{Resumen}

En este artículo se describe la ironía verbal como un fenómeno pragmático que debe ser explicado a partir del conocimiento del contexto y de las situaciones extralingüísticas. Para ello se presenta el análisis de un texto irónico, teniendo en cuenta las situaciones extralingüísticas que favorecen los procesos de inferencia. Se toman los diversos componentes contextuales como criterios para el reconocimiento de la ironía, se presenta el texto objeto de análisis y se señalan las situaciones contextuales que favorecen la comprensión del mismo. Se concluye con la afirmación de que sin el conocimiento pleno de las situaciones extralingüísticas no es posible completar el sentido de un texto irónico.

Palabras clave: contexto, inferencia, ironía, pragmática.

\begin{abstract}
This article describes verbal irony as a pragmatic phenomenon that need be explained from the knowledge of the context and the extra-linguistic situations. For this aim, this document presents the analysis of an ironic text, taking into account the extra-linguistic situations that favor the processes of inference. For recognize the irony, this manuscript takes the various contextual components as criteria and it includes the text under analysis and the contextual situations that promote the understanding of the text. It concludes with the statement that without the full knowledge of the extra-linguistic situations it is not possible to complete the meaning of an ironic text.
\end{abstract}

Keywords: context, inference, irony, pragmatics.

\footnotetext{
Profesor del Programa de Lengua Castellana de la Universidad Surcolombiana (Neiva, Colombia). Magíster en Lingüística del Instituto Caro y Cuervo. Estudiante del Doctorado en Lingüística de la Universidad de Antioquia. Correo electrónico: freddymier1231@hotmail.com
}

Cómo citar este artículo: Mier, F. (2017). El papel del contexto en la comprensión de la ironía verbal. Análisis pragmatico de una muestra. Enunciación, 22(1), 28-42. Artículo recibido: 29 de enero de 2016; aprobado: 25 de abril de 2016 


\section{Introducción}

La lingüística, bien lo sabemos, se centró en sus inicios en la estructura de la lengua, en el sistema que se aísla del uso. Los propósitos del estructuralismo eran comprensibles, pues una vez Ferdinand de Saussure le dio a la lingüística el estatus de ciencia, se buscaba que el objeto de estudio no se diluyera en análisis imprecisos. Según el mismo Saussure, "la ciencia de la lengua no solo puede prescindir de otros elementos del lenguaje, sino que solo es posible a condición de que esos otros elementos no se inmiscuyan" (2007, p. 64). Para el ginebrino, el habla no es esencial, sino un "accesorio [...] más o menos accidental" (p. 63) ${ }^{1}$. Por eso, la morfología, la sintaxis, la fonología, la fonética y la gramática en general ocuparon gran parte de los estudios lingüísticos iniciales. Se buscaba el aislamiento de aquello que fuera más allá de la cadena hablada. Sin embargo, Roman Jakobson, notable estructuralista, veía la necesidad de incluir el contexto en el esquema de la comunicación: "El destinador manda un mensaje al destinatario. Para que sea operante, el mensaje requiere un contexto de referencia [...] que el destinatario pueda captar, ya verbal, ya susceptible de verbalización" (Jakobson, 1984, p. 352).

Ya en los ochenta Van Dijk afirmaba:

[...] la reconstrucción teórica de las expresiones, en los niveles de forma y significado, debe ser completada por [...] la ACCIÓN. Esto es, una expresión no debería caracterizarse solamente en términos de su estructura interna y el significado

1 La posición de Saussure es comprensible, pues en una época muy marcada por el positivismo, solo buscaba darle estatus de ciencia a la lingüística. El alejamiento del habla como objeto de estudio fue, en su momento, una estrategia metodológica apropiada para el fin que se perseguía, que era definir un objeto de estudio para la naciente ciencia. que se le asigna, sino también en términos del acto realizado al producir tal expresión. (1984, p. 31)

En ese mismo sentido, Brown y Yule afirmaban:

[...] la idea de que una secuencia lingüística (una oración) puede ser completamente analizada sin tener en cuenta el "contexto" ha sido seriamente puesta en duda. Si el gramático de la oración desea hacer afirmaciones sobre la "aceptabilidad" de una oración al determinar si las secuencias producidas por su gramática son oraciones correctas de la lengua, está recurriendo implícitamente a consideraciones contextuales. Después de todo, ¿qué hacemos cuando nos preguntan si una determinada secuencia es "aceptable"? ¿No nos ponemos, inmediatamente y del modo más natural, a imaginar algunas circunstancias (es decir, un "contexto") en donde la oración podría ser empleada de modo aceptable? (1993, p. 47)

De ahí que la semántica haya abierto las puertas al sentido: ya no importaba solo el significado de las palabras y de las oraciones, sino también el sentido que ellas adquieren cuando se usan en contextos específicos ${ }^{2}$. El significado lingüístico (qué me dijo) ya no se podía analizar sin tener en cuenta el significado del hablante (qué me quiso decir) y el contexto en que se produce la cadena lingüística (cuándo y dónde).

Desde la segunda mitad del siglo XX, a partir de la teoría de los actos de habla de Austin (1962) y Searle (1969), se da un cambio de perspectiva y se comprende que los factores meramente lingüísticos necesitan de elementos

2 Para aclarar la diferencia entre significado y sentido, considérense las oraciones: i) "Todo niño mayor de tres años paga pasaje" y ii) "Todo niño menor de tres no paga pasaje". Las dos significan lo mismo, por cuanto la una presupone a la otra. No obstante, de acuerdo con la intención del enunciador y el contexto en el que aparecen, tienen sentidos distintos. En i) se enfatiza en que un niño mayor de tres años debe pagar pasaje, es decir, el factor dinero es el que predomina. En este caso suponemos que el enunciador puede ser el conductor de un bus. En ii) se enfatiza en que un niño menor de tres años no debe pagar pasaje, es decir, el factor que predomina son los derechos del niño. 
extralingüísticos para explicar los textos. Es así como en el análisis de la comunicación empieza a prevalecer el sentido sobre el significado.

Una vez se entiende que en el uso cotidiano de la lengua casi nunca nos comunicamos con significados literales, se empiezan a dar las condiciones para la naciente disciplina que busca explicar lo que la lingüística (debido a la forma como concibió su objeto de estudio) deja de lado.

Esta disciplina es la pragmática, que incorporó aspectos como el contexto situacional, las condiciones de uso, la intención del locutor, el significado no explícito, la forma como se producen los mensajes, el estatus de quien habla y escucha, las interpretaciones del interlocutor, etc. El análisis de la oración resultaba insuficiente si no se tenían en cuenta estos aspectos. Bien dice Escandell:

Si el enfoque pragmático se revela necesario para explicar muchas cuestiones que parecían simplemente gramaticales, no resultará extraño que también sea imprescindible en todos los aspectos para los que es consustancial el apelar a aquellos elementos que, siendo externos al sistema de la lengua, condicionan el uso que hacemos de ella. (2004, p. 179)

La pragmática atiende aspectos no propiamente lingüísticos, pero fundamentales en la comunicación real. Esos aspectos, antes desechados por la lingüística estructural, tienen que ver con comportamientos socioculturales, intenciones no explícitas y situaciones contextuales que motivan todo acto de enunciación.

Teniendo en cuenta que es necesario recurrir a esos elementos externos de la lengua que condicionan su uso, en este trabajo se describe la ironía verbal como un fenómeno pragmático en cuyo análisis es imprescindible el conocimiento del contexto situacional que circunscribe la cadena hablada, pues sin él no es posible completar el sentido en los procesos de inferencia. Para ilustrar el papel del contexto situacional en la comprensión de la ironía, hemos escogido como texto de análisis una columna del periodista Daniel Samper Ospina, publicada en la revista Semana.

Finalmente, en este trabajo se muestra la importancia que tiene el conocimiento del contexto situacional en la inferencia de la ironía verbal, y se plantean algunos elementos que ayudan a reconstruir ese contexto.

\section{Fundamentos conceptuales}

\section{La ironía como fenómeno pragmático}

Entendemos la ironía como un fenómeno pragmático en el que no siempre se cree lo contrario de lo que se dice, pues el enunciador es consciente de lo que expresa y orienta su discurso con marcas lingüísticas que le señalan al interlocutor el uso de la ironía (Padilla, 2008; Wilson y Sperber, 2004). Así las cosas, la ironía en este trabajo se entiende como un fenómeno que no solo expresa significados opuestos, sino también diferentes (Alvarado, 2006).

Como todo fenómeno pragmático, la ironía apela al contexto, a las situaciones, a los interlocutores y a las intenciones no manifiestas ${ }^{3}$. Tan importante es la ironía, que Ducrot afirma la necesidad de incluirla en la significación lingüística:

Si bien es cierto que la ironía y el humor no pertenecen a la lengua y son simplemente utilizaciones de la lengua, también es cierto que en todas ellas se puede expresar el humor y la ironía: es un fenómeno universal. Me parece necesario entonces incluir en los conceptos generales utilizados para describir la significación lingüística, nociones que prevean la posibilidad de estas

3 El contexto lo entendemos aquí, justamente, como una construcción dinámica y permanente donde confluyen todos estos aspectos (Calsamiglia y Tusón, 2008). 
utilizaciones humorísticas o irónicas. Una descripción de la lengua que no previera esas posibilidades, sería una descripción bastante incompleta. (1988, p. 22)

A decir verdad, la ironía, que es un recurso consciente e intencionado del hablante, se caracteriza por expresar lo "contrario"4 de lo que se cree y por no hablar de las cosas como realmente son, precisamente porque se basa en la simulación y la contradicción. Sin embargo, "el hablante que utiliza un enunciado irónico tiene que dejar a la vista marcas o indicios que permitan reconocer esta intención, ya que la inocencia es fingida y el enunciado irónico se construye con la colaboración del oyente" (Padilla, 2008, p. 298). Asimismo, el receptor debe tomar esas marcas o indicios y aportar a la inferencia, saltando del nivel semántico al pragmático para reconocer las verdaderas intenciones. En el proceso inferencial, "el comunicador proporciona una evidencia de su intención de transmitir un cierto significado, que el interlocutor deberá inferir a partir de esa evidencia suministrada" (Wilson y Sperber, 2004, p. 238).

En este sentido, el hecho de que un locutor tenga la intención de dejar una marca lingüística para que el interlocutor la interprete de acuerdo con lo que él quiere transmitir, de inmediato nos lleva a creer que la ironía no es, en sentido estricto, expresar lo contrario de lo que se dice. Según Alvarado:

En muchas ocasiones, lo que indica la ironía no es un significado opuesto, sino diferente. Por ello, estudiamos la ironía como fenómeno pragmático, puesto que para esta disciplina el hablante tiene una intención clara de comunicar algo; cuando utiliza un enunciado irónico, pretende así que su oyente infiera lo que no se ha dicho para

4 Se señala entre comillas porque en la ironía no siempre se dice lo contrario de lo que se cree. En nuestro texto objeto de análisis el enunciador cree lo que afirma de los personajes aludidos, aunque lo haga en forma de caricatura política. obtener el significado completo de su enunciación. (2006, p. 2)

En este sentido, tenemos la capacidad de inferir la ironía porque en el aprendizaje social hemos desarrollado algunas categorías mentales que nos permiten distinguir lo literal de lo figurado, es decir, ciertos mecanismos pragmalingüísticos que nos ayudan a reflexionar sobre la lengua en uso. En ese reconocimiento de intenciones se aplican principios de relevancia que, según Wilson y Sperber (2004), Ilevan al significado del hablante. Sin el uso de esos mecanismos no sería posible establecer comunicaciones coherentes con los demás, pues estaríamos constantemente preguntando: “¿Qué me quiso usted decir con esa expresión?", lo que resulta molesto y muestra de una incompetencia pragmática.

Por eso, un aspecto interesante que debe tenerse en cuenta en el análisis de la ironía es que el emisor siempre busca que ella sea entendida como lo que es: una ironía. Si alguien solo tomase el significado literal de una expresión irónica, el enunciador se sentiría, por un lado, insatisfecho consigo mismo por no utilizar los recursos irónicos adecuados; por otro, molesto con el receptor por no entender su enunciación como una ironía. Como dice Padilla:

[...] la ironía es responsabilidad de los dos interlocutores y [...] su estudio no puede limitarse a analizar las habilidades inferenciales del oyente, [pues] el hablante no deja el proceso interpretativo al azar, sino que [...] proporciona una serie de marcas o indicadores que sirven de guía al oyente y aseguran la eficacia comunicativa del enunciado. (2008, p. 283)

Por lo anterior, el propósito de este trabajo es mostrar que sin el conocimiento del contexto y de la situación no es posible comprender la ironía en un texto; se pretende analizar la forma en que un código lingüístico se comprende desde 
la inferencia, y cómo esta se construye desde el conocimiento del contexto.

\section{La importancia del emisor en el análisis pragmático}

En un análisis pragmático el emisor no debe considerarse como un codificador estático que produce una cadena hablada, sino como "un sujeto real, con conocimientos, creencias y actitudes, capaz de establecer toda una red de diferentes relaciones con su entorno" (Escandell, 1993, p. 31). Por eso es relevante saber quién produce un determinado discurso, pues en la cadena lingüística producida se dejan ver los conocimientos que ese sujeto tiene del mundo y la forma como los asume.

En el análisis del texto que hemos tomado como muestra es fundamental el conocimiento que tenemos del enunciador: los temas sobre los cuales escribe, el estilo de escritura, el tipo de textos que produce, etc.

\section{La importancia del destinatario}

El destinatario asume un papel protagónico en todo proceso de enunciación: no es un receptor cualquiera que se tropieza con un discurso. Como bien señala Escandell:

No puede considerarse destinatario a un receptor cualquiera [...]. El destinatario es siempre el receptor elegido por el emisor. Pero no solo eso: el mensaje está construido específicamente para él [...]. Incluso el escritor, que ni conoce ni tiene físicamente presentes a sus posibles receptores, prefigura una imagen ideal del tipo de personas a quienes le gustaría que estuviera dirigida su obra, y se construye un modelo de destinatario. $(1993$, p. 32)

De manera que tanto el emisor como el destinatario cobran importancia en el análisis pragmático de un fenómeno comunicativo.

\section{La situación contextual en el análisis pragmático}

En ocasiones importa más la forma como se dicen las cosas, las intenciones solapadas y el contexto en el que se dicen, que la cadena lingüística en sí. Una frase tan cotidiana como "¿por qué no te callas?" irrumpe en los medios de comunicación y llena titulares de prensa en cuestión de minutos porque fue pronunciada por el rey Juan Carlos I de España y dirigida al entonces presidente de Venezuela, Hugo Chávez, en la XVII Cumbre Iberoamericana de Jefes de Estado celebrada en Santiago de Chile el 10 de noviembre de 2007. Teniendo en cuenta la forma como fue dicha, la dignidad de quienes participaron y el contexto en que se produjo, la frase tuvo en su momento gran difusión en los medios.

El conocimiento de la situación (cultural, social o política) es de suma importancia para comprender los enunciados. Ningún análisis pragmático puede ser completo si se prescinde del contexto, pues en él "los enunciados se interpretan siempre dentro de un marco metacomunicativo que clasifica la situación de habla y el papel de los participantes" (Reyes, 1995, p. 20). Por eso, en este trabajo entendemos el contexto, según Calsamiglia y Tusón, como una permanente construcción que se da entre los interlocutores:

[...] el contexto es algo dinámico que quienes participan en un intercambio comunicativo tienen que ir construyendo -creando, manteniendo, cambiando e interpretando-. En ese proceso pueden concurrir -guiando y orientando- ciertos elementos como el entorno físico (culturalmente interpretado) y ciertas normas o tendencias de comportamiento colectivo interiorizadas cognitivamente en forma de marcos o guiones. (2008, p. 103) 


\section{La intención en la enunciación pragmática}

En la enunciación se establece una relación entre el emisor y el destinatario que está marcada por la actitud de uno y otro: lo que alguien dice corresponde con su deseo de expresar lo que piensa o siente; a su vez, lo que alguien recibe va acorde con lo que quiere recibir. En esa medida, la intención en un acto comunicativo se define como la voluntad de los interlocutores de querer expresar y recibir información, de acuerdo con lo que se siente y piensa o con la forma como se ve el mundo. Como bien señala Escandell:

Efectivamente, toda actividad humana consciente y voluntaria se concibe como reflejo de una determinada actitud de un sujeto ante su entorno. Por tanto, es legítimo tratar de descubrir qué actitud hay detrás de un determinado acto, es decir, preguntarse cuál es la intencionalidad de los actos y decisiones. (1993, p. 41)

La intención es más importante que lo que se dice. El propósito de ofender, ridiculizar o lograr algo, aunque no se manifieste explícitamente, supera en ocasiones lo que se dice. La máxima de calidad de Grice (1995) ("trate usted de que su contribución sea verdadera") se viola con frecuencia, precisamente para ajustar el discurso a intenciones.

En este trabajo se entiende que, independientemente del tipo de acto verbal que se produzca, lo importante es la intención que se tiene con su emisión; numerosos son los actos verbales asertivos cuya intención es desencadenar una sonrisa o una carcajada, como es el caso que ahora nos ocupa.

\section{Metodología}

Con el fin de mostrar cómo el conocimiento del contexto situacional es fundamental en la identificación de la ironía verbal, hemos tomado como objeto de análisis la columna de opinión "Lo que de verdad sucedió en el secuestro de Salud", del periodista Daniel Samper Ospina, publicada en la revista colombiana Semana, el 4 de junio de 2016. El texto trata sobre el secuestro de Salud Hernández-Mora, comunicadora española radicada en Colombia desde 1997. La periodista, secuestrada por el grupo guerrillero ELN en el municipio de El Tarra, Norte de Santander, estuvo desaparecida desde el 21 de mayo de 2016 hasta el 27 del mismo mes, cuando fue entregada a una comisión de la Iglesia católica. Tanto su secuestro como su posterior liberación generaron un sinnúmero de controversias en los medios de comunicación y en la opinión pública.

Luego de presentar el texto y de enunciar el contexto en que se produjo, se procede a analizar los elementos que intervienen en la identificación de la ironía. Para ello se toman fragmentos del texto que muestran las marcas de la ironía y se explican paralelamente en un cuadro los referentes contextuales y situacionales que nos ayudan a realizar con éxito los procesos de inferencia.

Por último, luego de mostrar los recursos utilizados por el enunciador para ubicar al receptor en el plano de la ironía, y de presentar las situaciones extralingüísticas cuyo conocimiento es fundamental para comprender con éxito el fenómeno irónico, se confirma que la ironía es un fenómeno pragmático que requiere de la convergencia de muchos elementos para su comprensión.

\section{Resultados y discusión}

\section{El texto objeto de análisis}

La elección del texto de análisis responde al interés de trabajar textos reales en uso, teniendo en cuenta las situaciones y los contextos de su producción (Parodi, 2008, p. 96).

He aquí el texto: 


\section{Lo que de verdad sucedió en el secuestro de Salud ${ }^{5}$}

\section{Por: Daniel Samper Ospina}

Después de celebrar la liberación de mi colega Salud Hernández-Mora, y de condenar el secuestro como arma de guerra, me inspiré en su legado periodístico y viajé a la zona del Catatumbo para reconstruir los hechos de primera mano: periodista de escritorio, como soy, hasta la fecha suponía que la expresión "meterse en la boca del lobo", aludía a la acción de ser deglutido por César Gaviria, y por eso sentí pavor mientras avanzaba por la polvorienta carretera del municipio de El Tarra, en especial cuando un retén del ELN me detuvo.

Como los verdaderos cronistas de guerra, fui al grano y pregunté al que parecía el líder si por allá recordaban a Salud Hernández.

El hombre palideció.

-Mire, periodista -dijo después de un largo suspiro-, en nuestra lucha hemos cometido muchos errores, pero ninguno como ese.

-Me alegra que comprendan que el secuestro es inadmisible -le respondí.

-No es eso -reviró-: es que jamás habíamos lidiado con alguien tan insoportable.

Durante media hora, entonces, y con la intervención creciente y excitada de sus camaradas, me contó los vejámenes a los que fue sometido: la forma en que Salud lo regañaba, lo llamaba rata humana y lanzaba vítores a Franco cada vez que alguien la interrumpía.

Me fui mientras se quedaban desahogando sus tormentosos recuerdos entre ellos. Caminé por la plaza hasta dar con sor Amanda Bedoya, la monja que vio a mi colega poco antes de su secuestro. Era afable. Parecía liberarse en la medida en que hablaba. "Nos tomamos un café -me relató-; me criticó los hábitos, como si los hábitos de ella fueran muy bonitos, y cuando le dije que mejor se devolviera, me dijo que le importaba un pimiento lo que le dijeran, y se fue manoteando. Sin pagar".

Estar en El Tarra y hablar de Salud no es tarea fácil. La gente mira a quien pronuncie ese nombre con prevención y nerviosismo. Así me sucedió con el propio comandante guerrillero que retuvo su computador, quien accedió a hablar en un rancho aledaño.

"Yo le quité los equipos pero noté que ella llevaba algo en el bolsillo. Entonces le pregunté:

-Doña Salud, ¿qué esconde?

Y ella me respondió:

- ¿Conde? ¿Mario Conde? Anda ya, si es un gran señor, un gran empresario.

Y durante media hora defendió al señor Conde".

Para ese momento, con una cacerola en la cabeza el presidente la buscaba en el Chocó, y Francisco Santos, confidencialmente, se había ofrecido en canje, solicitud que el mando desechó entre risas.

Conseguí que el guerrillero me pusiera en contacto con algunos de sus compañeros, quienes accedieron a hablar conmigo a cambio de mantener la reserva de sus alias, por temor a las repres. A las repres-alias.

"Yo le pasé la sudadera y cuando se la puso, el comandante preguntó:

- ¿Pero qué es esa facha?,

- Se llama Salud- le respondí.

5 Disponible en http://www.semana.com/opinion/articulo/danielsamper-salud-hernandez-lo-que-paso-en-su-secuestro/476293 
Entonces comencé a amarrarla y ahí fue cuando me gritó: “¿Pero cómo cojones me estáis poniendo la cabuya?; ¿quién coños os ha enseñado a ser guerrilleros?". "Y ahí me rapó la cuerda y se amarró a ella misma", recordó uno de ellos.

El encargado del rancho pidió la palabra: "Cuando le serví el arroz, dijo: '¿A eso Ilamas arroz, gilipollas?' y me lo tiró en la cara. Después se fue gritando: 'Vaya mierda de cambuche habéis armado', y no crea, uno se siente mal".

El comandante me cuenta que ese mismo día comenzaron las deserciones. "Yo le dije: 'Doña Salud, las cosas están pasando de castaño a oscuro', y ella me dijo que si eran castaño, ella hacía el prólogo".

En la tarde, los guerrilleros ya huían en desbandada. El Ejército informó, de manera redundante, que había dado de baja a alias Pitufo, aunque la verdad es que él también desertó. Era pitufo desertor.

"Ese día -confesó un miliciano-, el mando decidió que los centinelas que se quedaran dormidos tenían como castigo hablar con ella. Fue muy duro para todos. Nos inyectábamos café".

A partir de entonces comenzó lo peor: a Salud la picó un zancudo y el zancudo contrajo el zika; cinco de los centinelas castigados se volvieron franquistas y varios guerrilleros iniciaron una huelga de hambre para presionar la libertad de su rehén.

Consciente de la situación, el mando trató de resucitar el canje con Pachito, o incluso soltarla sin canje, o incluso soltarla y ofrecer algo más para que la recibieran. Pero ya cualquier esfuerzo era en vano.

"No la soportábamos más -reconoció el comandante-: uno maneja tatucos, pero no petardos".

Conseguí hacer contacto con alias Gabino, quien me recibió con los nervios destrozados: "¿Viene con ella?", indagó nervioso, mientras miraba a lado y lado. “¿Ella todavía está aquí?". Entonces me confesó: "Yo decía: brujas, que las hay, las hay; lo que no sabía era la nacionalidad. Dos días más y acaba con nosotros. Los muchachos estaban desesperados. Entonces buscamos la mediación de la Iglesia".

El desenlace ya se conoce: la guerrilla llamó al padre Torrado, quien adelantó una difícil

misión humanitaria: "Serás sacerdote, pero ya te voy a enseñar a dar de hostias, joder", le dijo la periodista cuando lo conoció.

Entonces comenzaron las tensas negociaciones para que Salud regresara a la vida civil, forcejeo que duró unos días, hasta que el mando consiguió que la aceptaran de regreso.

Semana, 4 de junio de 2016

\section{El autor del texto objeto de análisis}

Saber quién es el emisor de un discurso nos ayuda a reconocer sus intenciones, pues el estatus del locutor, su reconocimiento social y las constantes discursivas que lo caracterizan son fundamentales para entender si ese locutor habla en sentido literal, figurado o irónico. En nuestro caso, saber que Daniel Samper Ospina es un periodista y escritor colombiano cuyas columnas en la revista Semana se caracterizan por el sarcasmo, el humor, la sátira, la ironía, la hipérbole, la ambigüedad, la burla y la caricatura política es fundamental para entender que su texto es una invención, una parodia sobre un determinado suceso histórico ${ }^{6}$.

\section{El receptor del texto leído}

Ya hablábamos de la importancia que cobra el destinatario en la construcción de un discurso, pues la completitud del sentido solo se logra si el texto llega a manos del lector indicado. En

6 Si bien existen diferencias entre estos conceptos, no forma parte de los objetivos de este trabajo establecer con rigor la diferencia entre humor, burla, sátira, ironía, parodia y sarcasmo. Las entendemos como variantes de un mismo fenómeno pragmático. 
nuestro caso, solo un lector desprevenido sería incapaz de captar en este texto la sátira, la ironía, la burla y el sarcasmo. En el instante en que el lector infiere que no está leyendo propiamente una columna de opinión, sino una sátira que tergiversa la realidad política mediante el humor y la ironía, crea las condiciones contextuales necesarias para la inferencia. Para ello, el emisor ha tenido que proporcionarle al receptor ciertas pistas lingüísticas que permitan inferir el uso de la ironía. La identificación de la intención irónica del autor de inmediato convierte el texto en una caricatura, lo que no permite que los personajes reales aludidos presenten quejas, reclamos o demandas, pues se trata de una parodia. Como dice Saavedra: "ironía y humor son recursos de gran efectividad en cuanto permiten al locutor decir implícitamente algo sin crearle la responsabilidad real de haberlo dicho de forma explícita" (2012, p. 45).

En este sentido, no puede afirmarse que el enunciador de nuestro texto haya violado la máxima de calidad o veracidad de Grice; no se espera que en una caricatura haya veracidad y sinceridad. Como bien señalan Wilson y Sperber:

El lenguaje impreciso, la metáfora y la hipérbole no implican violación alguna de una máxima, sino que son, simplemente, rutas alternativas para alcanzar la relevancia óptima. Si un enunciado se entiende literal, imprecisa o metafóricamente será algo que dependa del ajuste mutuo entre contenido, contexto y efectos cognitivos, en su esfuerzo para satisfacer la expectativa completa de relevancia del hablante. (2004, pp. 259-260)

Es bien sabido que en todo proceso lector, "la comprensión se consigue cuando se cumple la intención comunicativa, o sea, cuando su destinatario reconoce la intención informativa" (Wilson y Sperber, 2004, p. 245). Vemos, entonces, que:
El éxito comunicativo consiste en la captación por parte del oyente del sentido que va asociado a la expresión emitida por el hablante. Para la correcta resolución del problema, son necesarios unos datos mínimos, datos que el oyente tiene que interpretar. Estos datos son, por un lado, las formas lingüísticas utilizadas, para descubrir el sentido del enunciado y su fuerza intencional o ilocutiva y, por otro, el conjunto de supuestos contextuales o contexto. (Catalá, 2001, pp. 135-36)

Es importante decir que el éxito comunicativo se garantiza cuando el destinatario puede hacer una lectura eficaz de las marcas que deja el enunciador. En nuestro caso es importante agregar que el tipo de lector de la revista Semana es el de un receptor culto e informado de lo que sucede a diario en el país; quizás por ello no le resultaría difícil identificar los aspectos contextuales que complementan el sentido. Si el mismo texto se hubiera publicado en un diario de orientación más popular, quizás no hubiese sido entendido en todo el sentido que el emisor quería transmitir. De manera que el destinatario, en un análisis pragmático, es fundamental para la completitud del sentido que se construye.

\section{Explicación de las situaciones extralingüísticas}

En el texto transcrito no se ha realizado ninguna marca tipográfica para señalar fenómenos de ironía, doble sentido o parodia, porque lo que se busca es que el lector haga sus inferencias a partir del conocimiento que tiene del contexto situacional en que se produce el texto.

Como sabemos que "el cometido de una pragmática de carácter inferencial es explicar cómo el oyente deduce el significado del hablante a partir de la evidencia proporcionada por este" (Wilson y Sperber, 2004, p. 238), cabe preguntarse, en primer lugar, qué indicios o marcas del emisor ubican al receptor en el plano de la ironía. Ante el título de la columna, un lector 
conocedor del contexto real en que se produjeron los hechos, deduce que el texto "Lo que de verdad sucedió en el secuestro de Salud" es una invención, pues justamente el secuestro de la periodista estuvo rodeado de incertidumbres, imprecisiones y desconocimiento de lo que sucedió el día en que desapareció. En segundo lugar, cuando el emisor se considera a sí mismo como un verdadero cronista de guerra nos ubica de inmediato en el plano de la invención, pues el conocimiento que tenemos de Samper Ospina es que es, justamente, un periodista de escritorio.

Por último, es necesario saber que la periodista Salud Hernández-Mora ha generado mucha polémica en el país por sus constantes y fuertes declaraciones en contra de ciertos personajes de la política nacional y de las guerrillas de las FARC y el ELN, al tiempo que suaviza su discurso con otros sectores. Seguida por unos y desestimada por otros, la periodista ha sido considerada, por un lado, como valiente al decir sin tapujos lo que piensa; por otro lado, se la ubica como conservadora y seguidora de una ideología de derecha.

A continuación se transcriben los fragmentos del texto con marcas tipográficas (negrilla y cursiva $)^{7}$ que señalan los fenómenos de sátira, ironía, hipérbole, burla, doble sentido, ambigüedad o sarcasmo. Al frente de las marcas se explica el contexto situacional con el fin de adquirir elementos que nos Ileven a inferir la ironía y descubrir las verdaderas intenciones del emisor.

\section{Fragmento}

\section{Explicación contextual}

(1) Después de celebrar la liberación de mi colega Salud Her- En el inicio que se marca con negrilla, el autor asume una nández-Mora, y de condenar el secuestro como arma de gue- actitud seria, de acuerdo con lo delicado del tema. Es una forrra, me inspiré en su legado periodístico y viajé a la zona del ma de mostrar que las siguientes apreciaciones serán serias y Catatumbo para reconstruir los hechos de primera mano.
(2) [...] hasta la fecha suponía que la expresión "meterse en la boca del lobo", aludía a la acción de ser deglutido por César Gaviria. fundamentadas. No obstante, cuando el emisor dice que se inspiró en su legado periodístico, está siendo irónico porque la periodista justamente ha sido criticada por esos viajes y por los personajes con los que se ha reunido. Recordemos que Salud Hernández es conocida por visitar zonas de conflicto con el fin de saber de primera mano lo que ocurre en las comunidades.

Usando la metáfora, el emisor se refiere al expresidente Gaviria como un lobo, es decir, como un político sagaz y astuto que interfiere en los asuntos políticos del país. "Meterse a la boca del lobo", en el contexto histórico, señala el hecho de que Salud decidió ir a un sitio donde corría peligro por ser territorio dominado por guerrillas.

3) [...] fui al grano y pregunté al que parecía el líder si por allá recordaban a Salud Hernández. El hombre palideció.
Mediante la exageración, el emisor nos muestra que la sola mención del nombre de Salud genera pavor dentro del grupo guerrillero.

El uso de la ambigüedad se da en este caso, pues el emisor da a entender que fue un error secuestrar a la periodista, cuando en realidad lo que afirma más adelante es que fue un error secuestrar a alguien tan insoportable.
(4) -Mire, periodista - dijo después de un largo suspiro- en nuestra lucha hemos cometido muchos errores, pero ninguno como ese.

-Me alegra que comprendan que el secuestro es inadmisible -le respondí.

-No es eso -reviró-: es que jamás habíamos lidiado con alguien tan insoportable.

7 Cuando en un mismo fragmento se señalan segmentos con negrilla y cursiva, se busca que el lector vea la ironía en cada segmento por separado. 
(5) [...] me contó los vejámenes a los que fue sometido: la Mediante el sarcasmo, el autor nos muestra la fuerte personaforma en que Salud lo regañaba, lo llamaba rata humana y lidad de la periodista, que en la vida real trata con agresividad lanzaba vítores a Franco cada vez que alguien la interrumpía. verbal a muchos personajes.

Por otra parte, a la periodista se le ha endilgado de ser seguidora del dictador español Francisco Franco. Eso es lo que quiere decir el emisor con lanzaba vítores a Franco.

(6) Caminé por la plaza hasta dar con sor Amanda Bedoya, la monja que vio a mi colega poco antes de su secuestro. Era afable. Parecía liberarse en la medida en que hablaba. "Nos tomamos un café -me relató-; me criticó los hábitos, como si los hábitos de ella fueran muy bonitos".

(7) El Ejército informó, de manera redundante, que había dado de baja a alias Pitufo.

(8) Estar en El Tarra y hablar de Salud no es tarea fácil. La gente mira a quien pronuncie ese nombre con prevención y nerviosismo.

(9) "Yo le quité los equipos pero noté que ella llevaba algo en el bolsillo. Entonces le pregunté:

- Doña Salud, ¿qué esconde?

Y ella me respondió:

- ¿Conde? ¿Mario Conde? Anda ya, si es un gran señor, un gran empresario.

Y durante media hora defendió al señor Conde"

(10) Para ese momento, con una cacerola en la cabeza el presidente la buscaba en el Chocó, y Francisco Santos, confidencialmente, se había ofrecido en canje, solicitud que el mando desechó entre risas.

(11) "Conseguí que el guerrillero me pusiera en contacto con algunos de sus compañeros, quienes accedieron a hablar conmigo a cambio de mantener la reserva de sus alias, por temor a las repres. A las repres-alias".

(12) "Yo le pasé la sudadera y cuando se la puso, el comandante preguntó:

- ¿Pero qué es esa facha?,

-Se llama Salud- le respondí".
Haciendo uso de la antanaclasis y de la ambigüedad léxica, señala que el comportamiento de la periodista no es el mejor. Y lo hace a partir de hábitos, que significa, por un lado, "modo especial de proceder o conducirse" y, por otro, "vestido o traje que usan los religiosos". En efecto, fue una religiosa (Amanda Bedoya) la que, según cuentan, vio por última vez a la periodista antes de su desaparición. Sin embargo, el emisor imagina lo que habría dicho, como una forma de realzar su ironía.

"Dar de baja" en la jerga militar equivale a eliminar al enemigo. En este caso, el autor apela a la ambigüedad léxica de baja para señalar que es una redundancia hablar de "de dar de baja" a un pitufo, puesto que ellos siempre son bajos o pequeños.

De nuevo, a través de la hipérbole, nos señala que Salud es muy temida por todos, hasta por la misma guerrilla. Es una forma de construir discursivamente la "personalidad" iracunda de la periodista.

Mediante la figura retórica del calambur, el emisor expresa la relación laboral que la periodista supuestamente sostuvo con el empresario y banquero español Mario Conde, que fue condenado a 20 años de prisión por desfalco al banco Banesto.

Es bien conocida por la opinión pública la estrecha relación de amistad entre la periodista y el ex vicepresidente Francisco Santos. Al decir que Santos se ofreció a canjearse por Salud, "solicitud que el mando desechó entre risas", el emisor apela a la burla para minimizar la figura política de Francisco Santos.

En el habla cotidiana es común el uso de formas apocopadas. Se usan, por ejemplo, "depre", en lugar de depresión; "cole", en vez de colegio. En este caso, "repres" es una forma apocopada de represalias. En un juego de palabras entre "alias" y "repres", se crea represalias para decir hiperbólicamente que los guerrilleros le tenían tanto miedo a la represión de Salud, que preferían mantener en reserva sus alias.

Apelando a la dilogía para provocar la ambigüedad léxica, el autor juega con los significados de la palabra "facha". En un sentido, "facha" se refiere al aspecto desaliñado de alguien (en este caso, alguien vestido con sudadera); en otro sentido, es una forma apocopada de llamar a alguien "fachista" o "fascista". En este caso se refiere a lo que se le endilga a la periodista: ser seguidora de Franco y de posiciones de derecha. 


\section{Fragmento}

(13) El comandante me cuenta que ese mismo día comenzaron las deserciones. "Yo le dije: 'Doña Salud, las cosas están pasando de castaño a oscuro', y ella me dijo que si eran castaño, ella hacía el prólogo".

\section{Explicación contextual}

De nuevo la hipérbole: la presencia de Salud Ileva a las deserciones dentro del grupo guerrillero.

La expresión "pasar de castaño a oscuro", significa que "las cosas se están complicando". De manera que con la expresión "si eran castaño, ella hacía el prólogo", el enunciador apela a la dilogía de castaño: nos recuerda que Salud hizo el prólogo de Mi confesión, un libro de Mauricio Aranguren Molina sobre el jefe paramilitar Carlos Castaño Gil. Es una forma de mostrar la tendencia ideológica de derecha que se le endilga a la periodista.

(14) "Ese día -confesó un miliciano--, el mando decidió que los centinelas que se quedaran dormidos tenían como castigo hablar con ella. Fue muy duro para todos. Nos inyectábamos café".

(15) A partir de entonces comenzó lo peor: a Salud la picó un zancudo y el zancudo contrajo el zika; cinco de los centinelas castigados se volvieron franquistas y varios guerrilleros iniciaron una huelga de hambre para presionar la libertad de su rehén.

(16) "No la soportábamos más -reconoció el comandante-: uno maneja tatucos, pero no petardos".

(17) "Yo decía: 'Brujas, que las hay, las hay'; lo que no sabía era la nacionalidad".

(18) "Serás sacerdote, pero ya te voy a enseñar a dar de hostias, joder".

Como hemos visto, no sería posible entender la sátira en el texto de Samper Ospina sin el conocimiento del contexto situacional, de las situaciones externas y del mundo sociopolítico. Como si se tratase de una obra dramática, el autor, a partir de sucesos y personajes reales, ha puesto en escena lo que, según él, sucedió en el secuestro de Salud Hernández. Para darle verosimilitud a su relato, utiliza personajes reales e históricos que participaron de los hechos. Además, el emisor se muestra como un conocedor de las situaciones, tal como supuestamente sucedieron, empleando formas temporales como: "para ese momento...",
Mediante la exageración nos muestra que los guerrilleros se inyectaban café para no dormirse y evitar así el castigo de hablar con Salud.

Por medio de la exageración, el autor nos muestra que estar al lado de Salud es lo peor que le puede pasar a alguien. Incluso a los zancudos.

El autor juega con la ambigüedad léxica de petardo, que significa, por un lado, "explosivo hecho con pólvora" (muy apropiado su uso en el contexto guerrillero) y, por otro, "persona aburrida y muy pesada para tratar con ella" (muy apropiada para la forma como el emisor viene tratando a Salud).

Apelando al sarcasmo, el enunciador, en boca de un guerrillero, dice que Salud es una bruja o persona malvada.

De nuevo el emisor apela a la dilogía y a la ambigüedad léxica: "dar de hostias" significa en España "dar un golpe o bofetada" (Salud es española). Por otra parte, entre "sacerdote" y "hostia" existe una relación semántica.

"entonces comencé a...", "ese mismo día", "a partir de entonces", "entonces buscamos...", etc.

Apelando a la invención y al uso irónico, sarcástico y burlesco del lenguaje, se desdobla y pone en boca de los personajes ridiculizados lo que piensa de ellos: de Salud, que es bravucona e ideológicamente de derecha; de Francisco Santos, que no tiene importancia política; de César Gaviria, que es un lobo político, etc. Como dice Reyes, "donde hay ironía, hay desdoblamiento del locutor. [...] Mientras el que dice algo en serio lo asume [...], el que dice algo irónicamente se desdobla: achaca esa afirmación ( $y$, con ella, ese punto de vista) a un ser ficticio, a un alter ego ridículo" (1994, p. 56). 
Así, como una pieza teatral, empleando el recurso ecoico de citar lo que otros supuestamente dicen, el emisor (como un narrador que observa los hechos) ha ido construyendo la ironía mediante la invención de un contexto situacional y la creación de diálogos ficticios que se basan en hechos históricos. Son hechos históricos, por ejemplo: el viaje de la periodista al municipio de El Tarra, el diálogo entre Salud y la religiosa Amanda Bedoya, la retención de Salud por parte de un grupo armado, el recibimiento de Salud por parte del sacerdote Ramón Torrado, etc. No obstante, esos hechos y personajes históricos se convierten en fenómenos irónicos cuando hacen eco de situaciones que "pudieron" haber sucedido o de expresiones que "pudieron" haberse dicho. Además, la ironía de alguna forma es una cita porque simula lo que alguien pudo haber dicho o hecho en una situación particular. Como dice Reyes:

La ironía es una cita porque el hablante repite o se hace eco de una proposición ajena, que proviene de un enunciado inmediato, o de un lugar común, o que representa lo que se suele decir en ciertas situaciones, o incluso lo que se podría decir: el hablante repite la proposición pero la aplica a un estado de cosas contrastante, volviéndola inadecuada, chocante. (1994, p. 51)

De manera que la inferencia de la ironía en el texto de Samper Ospina se logra, por un lado, mediante la identificación de recursos irónicos como la metáfora ("meterse en la boca del lobo"), la hipérbole ("nos inyectábamos café"), la ambigüedad léxica ("me criticó los hábitos, como si los hábitos de ella fueran muy bonitos"), el sarcasmo ("en nuestra lucha hemos cometido muchos errores, pero ninguno como ese"), entre otras figuras de pensamiento y recursos lingüísticos.

Por otro lado, la inferencia se logra a través del conocimiento del contexto situacional, ficticio o real, que el autor ha ido construyendo en el texto. Sin ese conocimiento no es posible que el interlocutor pueda cooperar en la completitud del sentido.

En el análisis de nuestro texto hemos podido comprobar que la ironía es un fenómeno pragmático, asociado al conocimiento del contexto situacional. Como bien afirman Calsamiglia y Tusón:

[...] el contexto se constituye como un concepto crucial y definitorio del ámbito de la pragmática y del análisis del discurso, ya que su consideración en la descripción y el análisis de los usos lingüísticos marcará la línea divisoria entre los estudios discursivos y los puramente gramaticales. (2008, p. 98)

Por tanto, en todo análisis pragmático (en este caso de la ironía), el conocimiento del contexto situacional no solo es fundamental, sino determinante en los procesos de inferencia. Como dice Kočman:

El papel del contexto en la pragmática no se debe subvalorar y [...] cualquier análisis pragmático del discurso y de sus enunciados, incluyendo entre estos la ironía, debe referirse al análisis de la relación del contexto con dicho discurso y dichos enunciados. (2011, p. 238)

Así las cosas, el objetivo del enunciador en nuestro texto de análisis no es otro que divertir y lograr que el receptor suelte una carcajada o esboce una sonrisa. Para ello apela al humor, la sátira, el sarcasmo y la ironía, convirtiendo su texto en una caricatura política. Sin embargo, muchos receptores no lo ven así y consideran que el texto de Samper Ospina es descortés y ofende a la periodista Salud Hernández. Algunos lectores de la columna online expresan en los comentarios:

\section{(1) Enrq Ortiz}

A ver si hace chistes de esos a costa de un familiar suyo secuestrado. Por ejemplo, si llegaran a secuestrar a su tristemente célebre tío expresidente, 
¿lanzaría sátiras sobre cómo entró dinero del Cartel de Cali para pagar el rescate? No soy ni uribista, ni me simpatiza mucho Salud Hernández, pero este tipo es un asco.

\section{(2) Déjame decirte que...}

Esta columna es ofensiva y para nada graciosa. Cómo reírse de una situación tan inhumana y degradante. Mejor búrlese de su tío Samper que ahora defiende al payaso de Maduro.

Otros, entendiendo que se trata de una caricatura, expresan en los comentarios:

\section{(3) Mar Fernández Carrillo}

Aquí no se está diciendo la verdad a nadie, simplemente se están diciendo pendejadas, bobadas, etc...

\section{(4) Floralba Ardila}

Magistral. Me he destornillado de la risa porque lo escrito, en buena medida es lo que yo pensé que pudo haber ocurrido. El fenómeno de la "papa caliente".

\section{(5) delfin22}

Jajajajajajajaja, deliciosa columna, hay que tener humor, mucho humor para escribir algo como esto, qué bien, lo siento por los resentidos jajajajajaja.

Por último, podemos decir que en el texto de Samper se violan, especialmente, dos máximas de calidad de Grice (1995, p. 516), que son las que más se relacionan con el fenómeno de la ironía:

1) "No diga usted lo que crea que es falso" y

2) "No diga usted aquello de lo cual carezca de pruebas adecuadas".

No obstante, podríamos decir que el enunciador no se preocupa si su texto resulta descortés o viola estas máximas, pues pragmáticamente se ubica en el plano de la ironía: a lo largo del texto codifica formas lógicas y le muestra al receptor las marcas lingüísticas que señalan este fenómeno. Además, el conocimiento del contexto situacional nos ubica en la lectura de un texto irónico. Como dice Haverkate, "el hablante que emita una locución declarativa con intención irónica no tiene otra finalidad que surtir un efecto perlocutivo humorístico" (1985, p. 362).

\section{Conclusiones}

Se ha demostrado que la lingüística, tal como concibió en sus inicios su objeto de estudio, resulta insuficiente para explicar todos los fenómenos del lenguaje que se presentan en el habla cotidiana, en los discursos académicos y científicos, incluso en un mundo audiovisual tan complejo como el nuestro. Un fenómeno como el de la ironía verbal, que requiere del uso metafórico del lenguaje y de formas lingüísticas que se alejan del uso referencial, directo y literal del lenguaje, debe ser explicado por disciplinas como la pragmática, cuyos análisis van más allá de la cadena hablada. Al tenerse en cuenta que en la ironía prima el significado del hablante y sus intenciones, es necesario asumirla como un fenómeno que requiere de la comprensión del contexto para completar los sentidos que se deben inferir.

En el análisis de un texto irónico como el de Samper Ospina hemos podido comprobar que es necesario el conocimiento del contexto tácito o explícito, de las situaciones externas y extralingüísticas y de los referentes históricos, para poder identificar las verdaderas intenciones de este enunciador: divertir y provocar una carcajada.

\section{Agradecimientos}

Este trabajo se deriva de un ejercicio de investigación realizado en el marco del seminario de Pragmalingüística impartido por la doctora Marta 
Albelda Marco en el Doctorado en Lingüística de la Universidad de Antioquia (Medellín, Colombia), en mayo de 2016. A la doctora Albelda, mi agradecimiento por sus valiosos aportes.

\section{Referencias bibliográficas}

Alvarado, M. (2006). Las marcas de la ironía. Interlingüística, 16, 1-11.

Austin, J. (1981). Cómo hacer cosas con palabras. Palabras y acciones (Genaro R. Carrió y Eduardo A. Rabossi, trads). Barcelona: Paidós.

Brown, G. y Yule, G. (1993). Análisis del discurso. Barcelona: Visor.

Bruzos, A. (2006). Sobre el problemático concepto de mención irónica. ELUA, 20, 33-55.

Bruzos, A. (2005). Análisis de la enunciación irónica: del tropo a la polifonía. Pragmalingüística, 13, 25-49.

Calsamiglia, H. y Tusón, A. (2008). Las cosas del decir. Manual de análisis del discurso. Barcelona: Ariel.

Catalá, M. (2001). Ironía, humor e inferencia: procesos cognitivos. Tendencias creativas de la publicidad actual. Acciones e investigaciones sociales, 12, 129-142.

Ducrot, O. (1988). Polifonía y argumentación. Conferencias del seminario "Teoría de la Argumentación y Análisis del Discurso". Cali: Universidad del Valle.

Escandell, M. (2004). Aportaciones de la pragmática. En J. Sánchez e I. Santos (eds.), Enseñar español como segunda lengua o lengua extranjera. Vademécum para la formación de profesores (pp. 179-198). Madrid: SGEL.

Escandell, M. (1993). Introducción a la pragmática. Madrid: Anthropos.

Grice, H. (1995). Lógica y conversación. En L. Valdés (ed.), La búsqueda del significado. Lecturas de filosofía del lenguaje (pp. 511-530). Murcia: Tecnos.
Haverkate, H. (1985). La ironía verbal: análisis pragmalingüístico. Revista Española de Lingüística, 15, 343-391.

Jakobson, R. (1984). Lingüística y poética. En Ensayos de lingüística general (pp. 347-395). Barcelona: Ariel.

Kočman, A. (2011). La ironía verbal como semejanza incongruente (Tesis doctoral inédita). Departamento de Lengua Española, Facultad de Filología, Universidad de Salamanca, Madrid.

Padilla, X. (2008). Claves para abordar la ironía en programas de ELE. De la competencia comunicativa a la competencia intercultural. Verba. Anuario Galego de Filoloxia, 35, 275-303.

Parodi, G. (2008). Lingüística de corpus: una introducción al ámbito. Revista de Lingüística Teórica y Aplicada, 46(1), 93-119.

Reyes, G. (1995). El abecé de la pragmática. Madrid: Arco/Libros.

Reyes, G. (1984). Polifonía textual: la citación en el relato literario. Madrid: Gredos.

Reyes, G. (1994). Los procedimientos de cita: citas encubiertas y ecos. Madrid: Arco/Libros.

Reyes, G. y Saavedra, L. (2012). Ironía y actos de habla. Análisis pragmático de la ironía verbal como recurso humorístico en un corpus de historietas en lengua española (Tesis de maestría). Recuperado de: http://repositorio.uchile.cl/bitstream/handle/2250/113638/Saavedra\%20Loreto. pdf? sequence $=1$ \&isAllowed $=y$

Saussure, F. (2007). Curso de lingüística general. Buenos Aires: Losada.

Searle, J. (1994). Actos de habla. Ensayo de filosofía del lenguaje. Barcelona: Planeta-Agostini.

Van Dijk, T. (1984). Texto y contexto. Semántica y pragmática del discurso. Madrid: Cátedra.

Wilson, D. y Sperber, D. (2004). La teoría de la relevancia. Revista de investigación lingüística, 7, 237-286. 